\title{
Readmission after esophageal resection for esophageal cancer: incidence and risk factors
}

\author{
Saurabh Singhal ${ }^{1}$, Sumeet K. Mittal ${ }^{2}$ \\ ${ }^{1}$ Department of GI-HPB Surgery and Liver Transplantation, Indraprastha Apollo Hospital, New Delhi, India; ${ }^{2}$ Department of Esophageal Surgery, \\ Norton Thoracic Institute, St. Joseph's Hospital and Medical Center, Phoenix, AZ, USA \\ Correspondence to: Sumeet K. Mittal, MD. Norton Thoracic Institute, St. Joseph's Hospital and Medical Center, 500 W. Thomas Rd., Ste. 500; \\ Phoenix, AZ 85013, USA. Email: Sumeet.Mittal@DignityHealth.org. \\ Provenance and Peer Review: This article was commissioned and reviewed by the Academic Editor Shuangjiang Li, MD (Department of Thoracic \\ Surgery and West China Medical Center, West China Hospital, Sichuan University, Chengdu, China). \\ Comment on: Park SY, Kim DJ, Byun GE. Incidence and risk factors of readmission after esophagectomy for esophageal cancer. J Thorac Dis \\ 2019;11:4700-7.
}

Submitted Apr 14, 2020. Accepted for publication Apr 28, 2020.

doi: $10.21037 /$ jtd-20-1670

View this article at: http://dx.doi.org/10.21037/jtd-20-1670

Esophageal resection for malignant neoplasms is a procedure associated with high morbidity-in fact, morbidity rates have been reported to be as high as $59 \%(1,2)$. Common early postoperative complications include cardiac and pulmonary complications (arrhythmias, pneumonitis, etc.), anastomotic complications (leak and stricture), vocal cord paralysis, conduit necrosis or failure, and chyle leak (2). Thromboembolic events, infection, and wound-related morbidities further complicate the postoperative course. The median hospital stay after an uncomplicated esophageal resection at high-volume centers is around 8 days (3). Early postoperative complications prolong the hospital stay and increase the incidence of unplanned readmissions after a patient has been discharged (3).

Hospital stay and readmission rates are considered potential markers of the success of the esophageal resection. It may seem intuitive that a potential reverse relationship exists between the hospital stay and readmission rates, where too much emphasis on reducing hospital stay may increase the likelihood of readmission, as some have reported (4). Several other published studies, however, dispute this finding by reporting a higher readmission rate in patients who had a previous longer hospital stay, which reflects the higher morbidity rate in this subgroup of patients (5).

The recent study "Incidence and risk factors of readmission after esophagectomy for esophageal cancer" by Park and colleagues at Yonsei University College of Medicine, South Korea reported a readmission rate of $13.4 \%$ within 30 days of discharge after esophageal resection (6). In their analysis, they found postoperative anastomotic leakage and wound-related problems to be significant risk factors predictive of readmission. They also reported a significant financial burden associated with readmission. Anastomotic strictures requiring balloon dilatation were reported in more than $30 \%$ of patients, and were the most common cause of readmission in their study, with other common causes being wound problems (18\%), pneumonia (15\%), and poor oral intake (10\%). Additionally, bowel dysfunction (including delayed gastric emptying and prolonged ileus) were present in approximately $13 \%$ of cases. Despite $21 \%$ of patients developing vocal cord palsy postoperatively, this was not a significant factor for readmission. Furthermore, $38 \%$ of patients who were readmitted required intervention for their associated complication(s). In this study, Park et al. emphasized the importance of a postoperative intensive patient education program to prevent common complications, such as aspiration due to vocal cord palsy and gastric fullness due to delayed gastric emptying. The mean hospital stay in their study (25.6 days) was longer than the average length of stay reported by most major centers (12-13 days) $(3,4,6)$.

Several authors have reported on factors associated with readmission after esophageal resection. Table 1 shows the reported factors associated with readmission in major 
Table 1 Studies reporting factors associated with readmission following esophageal resection for malignancy

\begin{tabular}{|c|c|c|c|c|c|}
\hline Author, year & Country & Patient population & $\begin{array}{l}\text { Study } \\
\text { participants (n) }\end{array}$ & $\begin{array}{l}\text { Readmission } \\
\text { rate }\end{array}$ & Factors associated \\
\hline $\begin{array}{l}\text { Kelly et al., } \\
2014 \text { (7) }\end{array}$ & USA & NSQIP (2011) & $1,400^{* *}$ & $13.5 \%$ & $\begin{array}{l}\text { Postoperative complications, chronic steroid use, } \\
\text { discharge to facility other than home }\end{array}$ \\
\hline $\begin{array}{l}\text { Fernandez } \\
\text { et al., } 2015 \text { (8) }\end{array}$ & USA & $\begin{array}{l}\text { SEER database } \\
(2002-2009)\end{array}$ & 1,744 & $18.6 \%^{\dagger}$ & $\begin{array}{l}\text { Comorbidity score } 3+\text {, urgent admission, urban } \\
\text { residence }\end{array}$ \\
\hline $\begin{array}{l}\text { Sundaram } \\
\text { et al., } 2015 \text { (4) }\end{array}$ & USA & $\begin{array}{l}\text { NSQIP database } \\
(2011-2012)\end{array}$ & 1,068 & $12.6 \%^{\dagger}$ & $\begin{array}{l}\text { Preoperative pulmonary disease, postoperative } \\
\text { wound-related complications, LOS }\end{array}$ \\
\hline $\begin{array}{l}\text { Shah et al., } \\
2015 \text { (3) }\end{array}$ & USA & $\begin{array}{l}\text { Single center } \\
(1993-2011)\end{array}$ & 306 & $13.7 \%^{\dagger}$ & $\begin{array}{l}\text { LOS, >1 postoperative complications (including cardiac, } \\
\text { pulmonary, septic, anastomotic leak, wound infection) }\end{array}$ \\
\hline $\begin{array}{l}\text { Chen et al., } \\
2016(11)\end{array}$ & USA & $\begin{array}{l}\text { NSQIP database } \\
(2005-2013)\end{array}$ & 4,483 & $12.8 \%^{\ddagger}$ & $\mathrm{BMI}>25 \mathrm{~kg} / \mathrm{m}^{2 *}$ \\
\hline $\begin{array}{l}\text { Bhagat et al., } \\
2018 \text { (5) }\end{array}$ & USA & $\begin{array}{l}\text { NSQIP database } \\
(2012-2015)\end{array}$ & 3,723 & $10.7 \%^{\ddagger}$ & $\begin{array}{l}\text { In-hospital UTI, prolonged LOS, post-discharge } \\
\text { infection, pulmonary, venous or thromboembolic } \\
\text { complications and UTI }\end{array}$ \\
\hline $\begin{array}{l}\text { Makiura et al., } \\
2018(12)\end{array}$ & Japan & $\begin{array}{l}\text { Single center } \\
(2011-2014)\end{array}$ & 95 & $10.5 \%^{\dagger}$ & Sarcopenia ${ }^{\star \star}$ \\
\hline $\begin{array}{l}\text { Goel et al., } \\
2020 \text { (13) }\end{array}$ & USA & NRD (2010-2014) & 13,282 & $19.4 \%^{\dagger}$ & $\begin{array}{l}\text { Perioperative blood transfusion, discharge to a nursing } \\
\text { facility, drug abuse, chronic renal failure, major illness on } \\
\text { APRDRG score }\end{array}$ \\
\hline
\end{tabular}

Pooled rate of readmission: $16.6 \%$. ${ }^{*}, \mathrm{BMI}>25 \mathrm{~kg} / \mathrm{m}^{2}$ was risk factor for post-discharge complications which in turn were associated with significantly higher rate of readmissions; ${ }^{*}$, Sarcopenia was not a significant factor for within 30 -day readmission but was significant if data was studied for within 90-day admission post discharge; ${ }^{\dagger}, 30$-day readmission following discharge; ${ }^{\ddagger}, 30$-day readmission following esophagectomy; ${ }^{*}$, described as resection of foregut cancers. APRDRG, All Patient Refined Diagnostic Related Group; BMI, body mass index; LOS, length of hospital stay; NRD, Nationwide Readmissions Database; NSQIP, National Surgical Quality Improvement Program; UTI, urinary tract infection; SEER, Surveillance, Epidemiology, and End Results.

published literature to date, with a pooled readmission rate of $16.6 \%$. Anastomotic leak is the Achilles heel of esophageal resection surgery and is the major determinant of overall hospital stay, in-hospital morbidity, and mortality. Leak after anastomotic stricture rates as high as $56 \%$ have been reported in the literature (14). Increased surgeon experience, advancements in surgical anastomotic techniques, and use of staplers have lowered the incidence of clinically significant leaks, which is reflected in shorter hospital stays and greater patient satisfaction $(1,14)$. In our opinion, stapled anastomosis by an expert surgeon is more reliable than hand-sewn anastomosis and achieves better short- and long-term outcomes (1). The effects of surgeon experience and technical innovation are further reflected in Table 1. The three studies that used the American College of Surgeons National Surgical Quality Improvement Program database showed a decreasing trend of readmission rates with the inclusion of more recent database entries. A similar trend is visible for patients in the Surveillance, Epidemiology, and End Results database as well. Hu and colleagues included a larger proportion of patients before 2012 and reported a higher readmission rate than Fernandez and colleagues $(8,10)$.

A minimally invasive technique for esophageal 
resection surgery has become the standard of practice. This technique has been reported to have better outcomes in terms of perioperative complications and in-hospital mortality; however, studies have shown no significant improvement in bowel-related complications, anastomotic leak, or recurrent laryngeal nerve palsy with the minimally invasive approach $(15,16)$. In addition, many centers are now adopting enhanced recovery after surgery (ERAS) protocols to enhance patient outcomes. A pooled analysis of randomized trials showed shorter hospital stays and decreased rates of anastomotic leak with the use of an ERAS protocol; however, there has been no significant effects on rates of postoperative complications and readmission after esophagectomy (17).

Unsurprisingly, co-morbidities and poor functional status at the time of admission are major risk factors for a poorer overall outcome and increased chances of readmission $(8,13)$. Most patients undergoing esophagectomy for treatment of esophageal adenocarcinoma in the US are generally older than 60 years of age. In addition, patients diagnosed with squamous cell carcinoma tend to be sarcopenic and cachectic. These are potentially non-modifiable risk factors. However, patient education and nutritional build-up in the preoperative phase should decrease the overall impact of these factors. In addition, detailed counseling of patients in the clinic as well as on the day before surgery may help level patients' expectations about common postoperative complications and required lifestyle changes. Wound complication is one of the major reasons for emergency room visits after discharge. Proper wound care and thorough wound assessment before discharge may decrease readmission rates due to wound complications. Wound complication is a potentially modifiable risk factor.

In conclusion, several identifiable risk factors may predict readmission following discharge after esophageal resection. Several technical and perioperative factors are particularly modifiable. Greater surgeon experience, adoption of advanced surgical techniques, increased patient education, perioperative critical care, and prevention of postoperative infectious, pulmonary, and cardiac complications may decrease readmission rates after esophagectomy for esophageal cancer. Reduced readmission rates may improve overall short- and long-term patient outcomes.

\section{Acknowledgments}

The authors are grateful to Clare Sonntag, who provided expert editorial assistance.
Funding: None.

\section{Footnote}

Conflicts of Interest: Both authors have completed the ICMJE uniform disclosure form (available at http://dx.doi. org/10.21037/jtd-20-1670). The authors have no conflicts of interest to declare.

Ethical Statement: The authors are accountable for all aspects of the work in ensuring that questions related to the accuracy or integrity of any part of the work are appropriately investigated and resolved.

Open Access Statement: This is an Open Access article distributed in accordance with the Creative Commons Attribution-NonCommercial-NoDerivs 4.0 International License (CC BY-NC-ND 4.0), which permits the noncommercial replication and distribution of the article with the strict proviso that no changes or edits are made and the original work is properly cited (including links to both the formal publication through the relevant DOI and the license). See: https://creativecommons.org/licenses/by-nc-nd/4.0/.

\section{References}

1. Singhal S, Kailasam A, Akimoto S, et al. Simple Technique of Circular Stapled Anastomosis in Ivor Lewis Esophagectomy. J Laparoendosc Adv Surg Tech A 2017;27:288-94.

2. Low DE, Kuppusamy MK, Alderson D, et al. Benchmarking Complications Associated with Esophagectomy. Ann Surg 2019;269:291-8.

3. Shah SP, Xu T, Hooker CM, et al. Why are patients being readmitted after surgery for esophageal cancer? J Thorac Cardiovasc Surg 2015;149:1384-9; discussion 1389-91.

4. Sundaram A, Srinivasan A, Baker S, et al. Readmission and risk factors for readmission following esophagectomy for esophageal cancer. J Gastrointest Surg 2015;19:581-5; discussion 586.

5. Bhagat R, Bronsert MR, Juarez-Colunga E, et al. Postoperative Complications Drive Unplanned Readmissions After Esophagectomy for Cancer. Ann Thorac Surg 2018;105:1476-82.

6. Park SY, Kim DJ, Byun GE. Incidence and risk factors of readmission after esophagectomy for esophageal cancer. J Thorac Dis 2019;11:4700-7.

7. Kelly KN, Iannuzzi JC, Rickles AS, et al. Risk factors 
associated with 30-day postoperative readmissions in major gastrointestinal resections. J Gastrointest Surg 2014;18:3543; discussion 43-4.

8. Fernandez FG, Khullar O, Force SD, et al. Hospital readmission is associated with poor survival after esophagectomy for esophageal cancer. Ann Thorac Surg 2015;99:292-7.

9. Stitzenberg KB, Chang Y, Smith AB, et al. Exploring the burden of inpatient readmissions after major cancer surgery. J Clin Oncol 2015;33:455-64.

10. Hu Y, McMurry TL, Stukenborg GJ, et al. Readmission predicts 90-day mortality after esophagectomy: Analysis of Surveillance, Epidemiology, and End Results Registry linked to Medicare outcomes. J Thorac Cardiovasc Surg 2015;150:1254-60.

11. Chen SY, Molena D, Stem M, et al. Post-discharge complications after esophagectomy account for high readmission rates. World J Gastroenterol 2016;22:5246-53.

12. Makiura D, Ono R, Inoue J, et al. Impact of Sarcopenia on Unplanned Readmission and Survival After Esophagectomy in Patients with Esophageal Cancer. Ann

Cite this article as: Singhal S, Mittal SK. Readmission after esophageal resection for esophageal cancer: incidence and risk factors. J Thorac Dis 2020;12(9):4608-4611. doi: 10.21037/jtd-201670
Surg Oncol 2018;25:456-64.

13. Goel NJ, Iyengar A, Kelly JJ, et al. Nationwide Analysis of 30-Day Readmissions After Esophagectomy: Causes, Costs, and Risk Factors. Ann Thorac Surg 2020;109:18593. Erratum in: Corrigendum. Ann Thorac Surg 2020;109:1313.

14. Orringer MB, Marshall B, Iannettoni MD. Eliminating the cervical esophagogastric anastomotic leak with a sideto-side stapled anastomosis. J Thorac Cardiovasc Surg 2000;119:277-88.

15. Yibulayin $\mathrm{W}$, Abulizi S, Lv H, et al. Minimally invasive oesophagectomy versus open esophagectomy for resectable esophageal cancer: a meta-analysis. World J Surg Oncol 2016;14:304.

16. Sundaram A, Geronimo JC, Willer BL, et al. Survival and quality of life after minimally invasive esophagectomy: a single-surgeon experience. Surg Endosc 2012;26:168-76.

17. Triantafyllou T, Olson MT, Theodorou D, et al. Enhanced recovery pathways vs standard care pathways in esophageal cancer surgery: systematic review and meta-analysis. Esophagus 2020;17:100-12. 